\title{
Videothoracoscopic lobectomy for bronchiectasis and extrapulmonary sequestration in a case Kartagener syndrome with pectus excavatum
}

\author{
Pektus ekskavatumlu bir Kartagener sendromu hastasında bronşektazi ve ekstrapulmoner \\ sekestrasyon nedeniyle videotorakoskopik lobektomi
}

\author{
Ümit Aydoğmuş (1)
}

Department of Thoracic Surgery, Medicine Faculty of Pamukkale University, Denizli, Turkey

\begin{abstract}
Kartagener syndrome is a rare condition. A 21-year-old female patient was under follow-up for five years by the chest diseases clinic due to recurrent cough, sputum production and wheezing, and she was diagnosed with Kartagener syndrome. The patient underwent surgery, when her symptoms could not be managed by medical therapy. The presence of extrapulmonary sequestration and pectus excavatum accompanied by Kartagener syndromerelated dextrocardia further complicated the performance of videothoracoscopic surgery. However, the patient was discharged without any complications. It should be considered, particularly in lower lobe bronchiectasis that undetected sequestration may be present. Videothoracoscopic surgery provides excellent exposure for hilar structures and can be successfully and safely performed by way of a careful dissection, even in a bronchiectasis case with multiple anatomic anomalies.
\end{abstract}

Keywords: Kartagener syndrome, pulmonary sequestration, videothoracoscopic lobectomy.

Kartagener syndrome (KS) is a rare disease with a reported incidence of $1 / 32,000 .{ }^{[1]}$ To date, there is no cure for KS. Acceptable morbidity rates and satisfactory long-term outcomes can be obtained with surgical treatment of bronchiectasis. Videothoracoscopic surgery is recommended, as it allows for a faster recovery. ${ }^{[2]}$

Cases with KS may be accompanied by additional pathologies, such as ventral septal defects or congenital chest wall deformity ${ }^{[3]}$ Herein, we report a case of KS
$\ddot{O} Z$

Kartagener sendromu nadir bir hastalıktır. Yirmi bir yaşında kadın hasta, tekrarlayan öksürük, balgam ve hırıltılı solunum nedeniyle göğüs hastalıkları kliniğinde beş yıldır takip altındaydı ve Kartagener sendromu tanısı konuldu. Semptomları medikal tedavi ile kontrol altına alınamayan hastaya cerrahi uyguland1. Kartagener sendromuna bağl1 dekstrokardi dışında ekstrapulmoner sekestrasyon ve pektus ekskavatum varlığı videotorakoskopik cerrahi için zorluklar oluşturdu. Bununla birlikte, hasta koplikasyon görülmeden taburcu edildi. Özellikle alt lob bronşektazilerinde fark edilmemiş sekestrasyon bulunabileceği mutlaka düşünülmelidir. Videotorakoskopik cerrahi, hiler yapılara mükemmel görüş sağlar ve çoklu anatomik anormalliği olan bir bronşektazi hastasında dahi başarılı ve güvenli bir şekilde uygulanabilir.

Anahtar sözcükler: Kartagener sendromu, pulmoner sekestrasyon, videotorakoskopik lobektomi.

accompanied by sequestration and pectus excavatum (PE) who underwent videothoracoscopic lobectomy and discuss surgical challenges.

\section{CASE REPORT}

A 21-year-old female patient applied to the chest diseases clinic with complaints of cough, sputum, and wheezing. The patient was undergoing asthma therapy for five years and had a history of frequent admissions to the hospital. Minor hemoptysis

Received: April 27, 2020 Accepted: May 27, 2020 Published online: October 20, 202

Correspondence: Ümit Aydoğmuş, MD. Pamukkale Üniversitesi Tıp Fakültesi, Göğüs Cerrahisi Anabilim Dalı, 20070 Kınıklı, Denizli, Türkiye. Tel: +90 428 - 2121039 e-mail: umitbile@yahoo.com 

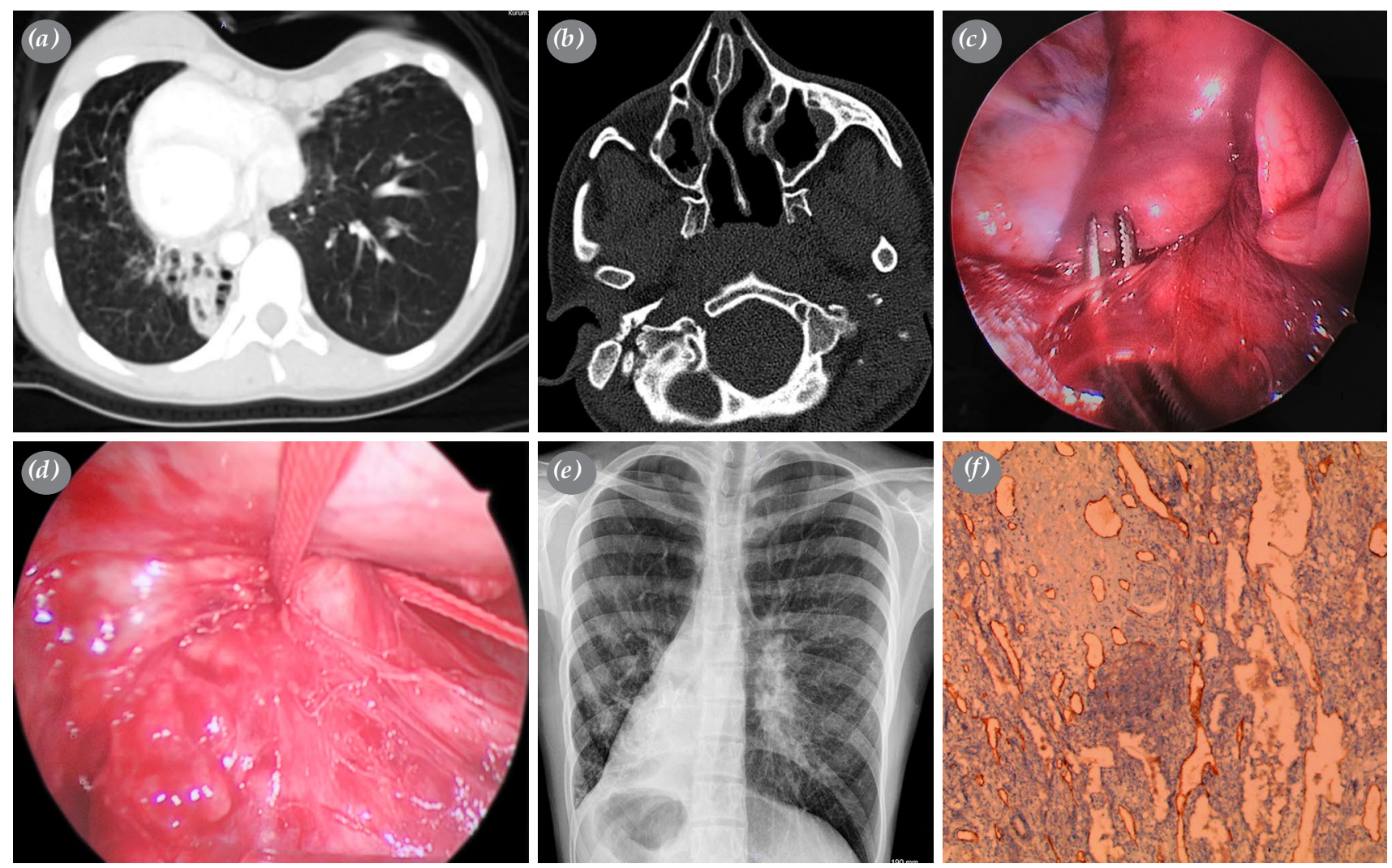

Figure 1. (a) A computed tomography scan of the chest. (b) Sinus tomography. (c) Postoperative chest X-ray. (d) Vascular structures extending from the mediastinum to the lower lobe of the lung. (e) Thoracoscopic view of the lower lobe vein. (f) Histological view.

complaints controlled by medical treatment were reported four times during the last six months. The posteroanterior chest X-ray showed a consolidated and infiltrative area in the right lower zone shadowed by the heart image accompanies dextroposition of heart. Thoracic computed tomography (CT) showed $\mathrm{PE}$, bronchiectasis, and a consolidated area that was confined to the base of the inferior-posterior segment of the right lung (Figure 1a). Cylindrical bronchiectasis regions were also observed in the lingular segment of the left lung. A sinus CT revealed diffuse chronic sinusitis (Figure 1b). The patient was diagnosed with $\mathrm{KS}$ and a decision to perform surgery was made based on the presence of recurrent complaints that could not be explained by sinusitis and did not improve with full physiotherapy and medical treatment. The patient was informed about the treatment options and possible complications. A written informed consent was obtained from the patient. Necessary permission regarding the presentation of this case report in scientific meetings and journals providing that her identity was kept confidential was also obtained from the patient.
As standard double-lumen tubes are not suitable in cases with situs inversus for double-lumen intubation, we rotated a 35-F right double-lumen tube by 180 degrees and placed it in the left main bronchus guided by fiber optic bronchoscopy. Lower lobectomy was performed using three-port incisions. Similar to the radiological data, during the procedure, there was no smaller resection possibility other than lobectomy, since the entire lobe was destructed. The vessels extending from the aorta to the lung were ligated during surgery using polymer clips at the pulmonary ligament level which were, then, divided (Figure 1c). The accompanying PE deformity and adhesions related to chronic infections resulted in a prolonged surgery duration (205 min) (Figure 1d).

No undesired events occurred during the postoperative period. The thoracic drain was removed on postoperative Day 5, and the patient was discharged on postoperative Day 7 (Figure 1e).

Pathological examination showed mononuclear inflammatory cell infiltration and atrophic bronchioles around the bronchus. A large number of cystic 
rudimentary lymphatic vessels, which were positively stained with D2-40, were also observed. The final pathological examination result was reported as sequestration along with bronchiectasis (Figure 1f).

\section{DISCUSSION}

Kartagener syndrome is an autosomal recessive genetic disorder that is accompanied by chronic sinusitis, bronchiectasis, and situs inversus. ${ }^{[1,3]}$ Videothoracoscopic pulmonary resection has recently started to be performed more frequently thanks to its advantages such as low morbidity, early discharge, and comfortable postoperative period. ${ }^{[2]}$ In our case, videothoracoscopic surgery was performed after which the patient was discharged without any complications.

Dissection is usually complicated by chronic infectious and inflammatory processes in patients with bronchiectasis. ${ }^{[4]}$ The present patient was challenged not only by the difficulties in dissection, but also by the presence of situs inversus which made the patient unsuitable for a double-lumen endotracheal tube placement. Thus, a right-sided double-lumen tube was placed in the guidance of a bronchoscope. Two-port approaches are preferred in our clinic for videothoracoscopic lower lobectomies, although in the present case, a three-port approach was preferred due to the presence of PE and dextrocardia.

Extrapulmonary sequestrations are hereditary malformations. ${ }^{[5]}$ The assessment of the arterial blood supply before scheduling a resection can facilitate surgery. ${ }^{[5]}$ The clinical findings of the present patient did not raise suspicions of pulmonary sequestration, and preoperative radiological work-up also did not suggest sequestration. Furthermore, it should be considered that the anatomical variations of the left lung are much higher, even in patients without congenital anomalies. ${ }^{[6]}$ The direct abnormal vascularization from the aorta observed during a clearer surgical exploration of the hilar structures and careful dissection, using a videothoracoscopic approach, was found upon a pathological examination to be associated with sequestration. Surgical dissection should be performed carefully in inflammatory diseases such as bronchiectasis. The videothoracoscopic approach provides a better view for mediastinal structures. Thus, vascular structures of sequestration were noticed which can hardly be detected during open surgery (Figures 1d-f).

In conclusion, while planning surgery, it is critical to have knowledge of all anatomical variations in advance. It is advantageous to recognize the displacement of the anatomical structures in patients with Kartagener syndrome and the arterial supply of extrapulmonary sequestration by preoperative evaluation. It should be kept in mind that there may be other accompanying anomalies in cases with known anatomical variations, even when they are not detected in preoperative radiological evaluations. The videothoracoscopic approach provides a direct view of the mediastinal structures and, thus, it can be preferred in such cases.

\section{Declaration of conflicting interests}

The author declared no conflicts of interest with respect to the authorship and/or publication of this article.

\section{Funding}

The author received no financial support for the research and/or authorship of this article.

\section{REFERENCES}

1. Lin H, Cao Z, Zhao X, Ye Q. Left middle lobectomy for bronchiectasis in a patient with Kartagener syndrome: A case report. J Cardiothorac Surg 2016;11:37.

2. Zhang P, Zhang F, Jiang S, Jiang G, Zhou X, Ding J, et al. Video-assisted thoracic surgery for bronchiectasis. Ann Thorac Surg 2011;91:239-43.

3. Shukla V, Fatima J, Karoli R, Chandra A, Khanduri S. An unusual presentation of Kartagener's syndrome. J Assoc Physicians India 2011;59:266-7.

4. ten Hacken NH, Wijkstra PJ, Kerstjens HA. Treatment of bronchiectasis in adults. BMJ 2007;335:1089-93.

5. Schlöricke E, Hoffmann M, Kujath P, Facklam J, Henning M, Wissgott C, et al. Management of the therapy of pulmonary sequestration: A retrospective multicentre study. Zentralbl Chir 2016;141 Suppl 1:S50-7.

6. Murlimanju BV, Massand A, Madhyastha S, Pai MM, Prabhu LV, Saralaya VV. Anatomical variations of the arrangement of structures at the pulmonary hilum: A cadaveric study. Surg Radiol Anat 2017;39:51-6. 